\section{Oppdatert og meget nyttig om ryggsmerter}

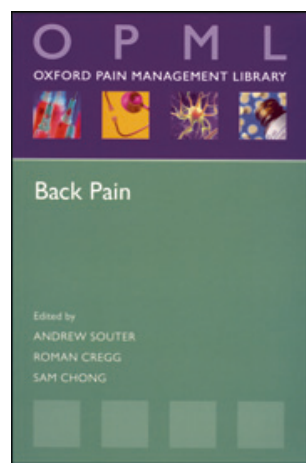

Andrew Souter, Roman Cregg, Sam Chong, red.

\section{Back pain}

159 s, tab, ill. Oxford: Oxford University Press, 2012. Pris GBP 20

ISBN 978-0-19-960977-2

I løpet av 152 lettleste sider settes ryggsmerter i et sosiobiologisk perspektiv. Forfatterne gir en oversiktlig og praktisk fremstilling over utredning og behandling av ryggsmerter, som er helt $i$ tråd med den mest oppdaterte norske forståelse i 2013.

Boken er gitt ut i serien OPML - Oxford pain management library. Den er redigert i 15 kapitler skrevet av utvalgte praktiserende klinikere. Det er referanselister etter hvert kapittel.

Det er tre hoveddeler. I den første delen tar forfatterne for seg hvordan forståelsen av ryggsmerter som plage eller sykdom påvirker behandling og retur til arbeid. Historisk går de 80 år tilbake i tid til «the railway spine syndrome», hvor rygg- og nakkesmerter ble definert som sykdom hos store deler av befolkningen. Denne delen ender med dagens forståelse, hvor man har et kognitivt perspektiv på smerte. Behandleren skal forklare pasientens ryggsmerte, hva utredningen viser, og hva behandlingen vil gjøre. Det legges vekt på å formidle at ryggsmerten i seg selv ikke er farlig, siden denne oppfatningen har forsinket arbeidsrettet rehabilitering av pasienter med kroniske ryggsmerter.

Den neste delen omhandler utredning, anatomi og patofysiologi, MR-undersøkelser med bildeeksempler og nevrofysiologiske tester, i tillegg til tolkingen og nytten av disse. Det legges opp til en bredt anlagt utredning fra første stund. Et oversiktlig detaljert flaggsystem for risikofaktorer og forhold som hindrer bedring virker lett å bruke. I tillegg til de kjente røde flaggene, er det gule, sorte, blå og oransje flagg.

Røde flagg betyr fysiske faresignaler, f.eks. lammelse som tyder på alvorlig nerverotaffeksjon som krever rask operasjonsvurdering.

Gule flagg står for sju psykososiale faktorer forbundet med kronifisering og lang sykmelding.

Sorte flagg er konkrete forhold på arbeidsplassen som hindrer pasienten i å komme tilbake.

Blå flagg betyr forhold på arbeidsplassen som pasienten mener hindrer friskmelding, delt i sju kategorier.

Oransje flagg står for depresjon og annen psykisk lidelse.

Den tredje og siste delen består av behandlingskapitler som tar for seg fysioterapi, kiropraktikk, akupunktur, transkutan nervestimulering, psykologiske faktorer, medikamentell smertebehandling, kirurgi og et eget kapittel om håndtering av pasienter med mislykkede ryggoperasjoner. Kiropraktorbehandling er spesielt effektiv ved kroniske korsryggsmerter. Med glede merket jeg meg som nevrolog at den kiropraktorbehandlingen som har vist seg effektiv på cervikogen hodepine, er i øvre thoracalcolumna uten at nakken manipuleres.

Dette er en nyttig bok for alle som behandler ryggpasienter, fra turnuslege til nevrolog, ortoped og nevrokirurg. Forfatterne tar for seg en stor pasientgruppe som ofte mottar multidisiplinær behandling, noe som derfor setter ens eget fagområde i et viktig, helhetlig perspektiv. Jeg anbefaler boken og mener at den bør inngå i standardbiblioteket på legekontoret.

\section{Systematisk lærebok i infeksjonsmedisin}

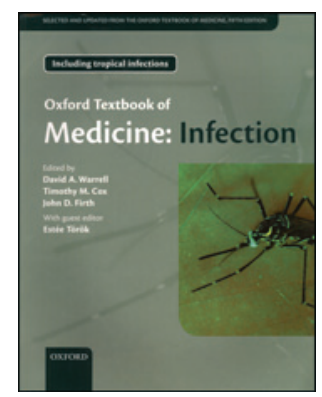

\author{
David A. Warrell, Timothy M. Cox
}

John D. Firth et al, red.

Oxford texbook of medicine: infection

900 s, tab, ill. Oxford: Oxford University Press, 2012. Pris GBP 95

ISBN 978-0-19-965213-6

Oxford texbook of medicine: infection er en nyutgivelse av infeksjonskapitlet i den store læreboken i indremedisin, Oxford texbook of medicine, 5. utgave (2012). Denne læreboken er en av de mest anerkjente og mest leste lærebøkene i indremedisin. Den ble første gang utgitt i 1983.

Denne systematiske og oversiktlige læreboken i infeksjonsmedisin er på 870 sider og har 13 hovedkapitler og 121 underkapitler. Boken innledes med fire generelle kapitler: Vert-mikrobe forholdet, Pasienten med mistenkt infeksjon, Immunisering og Reise- og ekspedisjonsmedisin. I resten av teksten presenterer forfatterne de ulike virussykdommene, bakterielle sykdommer, sopp, protozoer og parasitter. Hver infeksjon er beskrevet i et eget underkapittel.

Kvaliteten er høy idet omtalen av hver sykdom er skrevet av de fremste internasjonale ekspertene innen sitt fagfelt. Hver infeksjon omtales først med et sammendrag som gir leseren en rask og god oversikt over sykdommen. De 121 underkapitlene er bygd opp på samme måte med beskrivelse av mikrobe, patogenese, epidemiologi, kliniske manifestasjoner, diagnose, behandling og forebygging. Boken omfatter alt fra de vanlige infeksjonene vi finner i Norge, inklusive barnesykdommer, til eksotiske og nyoppdagede tropesykdommer. Den er oppdatert med nyoppdagede virussykdommer og de aktuelle utbruddene av svineinfluensa i 2009 og utbruddet i Nord-Tyskland i 2011 med hemolytisk uremisk syndrom forårsaket av E coli 0104.

Det største minuset er at en del sentrale infeksjoner ikke er kommet med, men blitt igjen i hovedboken. Om man ønsker informasjon om urinveisinfeksjoner, endokarditt, septisk artritt, osteomyelitt eller infeksjoner i sentralnervesystemet, henvises man til organkapitlene i hovedboken. Meningokokkinfeksjoner omtales imidlertid her, i et kapittel som for øvrig er skrevet av den eneste norske bidragsyteren, Petter Brandtzæg.

Boken er enkel, morsom å lese og lett å finne frem i. Den er samtidig detaljrik og konsis nok til at den fungerer godt både som oppslagsverk og for den som vil lære mer om de ulike infeksjonene. De over 250 fargebildene har høy kvalitet og er til god hjelp i diagnostikken av pasienter. Tabeller og plansjer bidrar ytterligere til økt forståelse. Kapitlene har henvisninger til sentrale bøker og publikasjoner.

Infeksjonsmedisin er et globalt fag, og på grunn av økt reisevirksomhet og innvandring ser vi stadig flere importinfeksjoner. Målgruppen vil både være spesialister i infeksjonsmedisin og i mikrobiologi, i tillegg til alle som spesialiserer seg innen disse disiplinene. Medisinstudenter og helsepersonell med interesse for infeksjonssykdommer, og som er engasjert i reisemedisin og internasjonal helse, vil også kunne ha glede og nytte av boken.

Det finnes i tillegg en nettutgave og en paperbackutgave, og prisen er overkommelig. Som nevnt over, bør leseren ha tilgang til hovedboken, Oxford textbook of medicine, for å få tilgang til en del viktige emner som ikke omtales. Den finnes også i nettutgave.

Jeg anbefaler denne flotte boken. Oxford University Press bør imidlertid oppfordres til å ta med de andre infeksjonene fra hovedboken i neste utgave.

Haakon Sjursen

Medisinsk avdeling

Haukeland universitetssykehus 